\title{
Case report: pulmonary nocardiosis caused by Nocardia exalbida in an immunocompetent patient
}

\author{
Seitaro Abe ${ }^{1}$, Yoshinari Tanabe ${ }^{1 *} \mathbb{D}$, Takeshi Ota ${ }^{1}$, Fumio Fujimori', Akira Youkou ${ }^{2}$ and Masato Makino ${ }^{1}$
}

\begin{abstract}
Background: Nocardiosis is known as an opportunistic infection in immunocompromised hosts, but it occasionally has been reported in immunocompetent patient. The Nocardia exalbida is first-reported in 2006 from Japan, and a few cases of have been reported in only immunocompromised host, and the characteristic is still unclear. We herein describe the first case of pulmonary nocardiosis caused by N. exalbida in an immunocompetent patient.

Case presentation: A77 -year-old Japanese man was admitted to our hospital on November 2, 2018. He was a lifelong non-smoker with no childhood history of respiratory disease. He had a medical history of dyslipidemia. One month before this admission fevers, sputum, mild cough were developed and he was evaluated in a clinic near our hospital. His diagnosis was community acquired pneumonia within his right middle lobe. He was treated with ceftriaxone $1 \mathrm{~g}$ /day intravenously for a week, however his symptoms relapsed a few days later. So, the physician retried ceftriaxone for another 3 days, but his symptoms did not improve. He was referred to our hospital. He was treated with sitafloxacin as an outpatient for a week, however his symptoms got worse. The chest CT showed consolidation and atelectasis in his right middle lobe. Low density area was scattered in consolidation, and right pleural effusion was observed.

The patient was diagnosed with pulmonary abscess and he was admitted. Administration of piperacillin/tazobactam improved his condition. We switched antibiotics to amoxicillin/clavulanate, and he was discharged. After 2 weeks, he relapsed and was admitted again. After administration of piperacillin/tazobactam for 3 weeks, we perform bronchoscopy and Nocardia species were cultured from samples of the bronchial wash. The isolates were identified as N. exalbida using $16 \mathrm{~S}$ rRNA gene sequencing. We prescribed Trimethoprim / Sulfamethoxazole (TMP/SMX) for 4 months. Then we switched to minocycline for renal dysfunction caused from TMP-SMX for 1 more month. After 5 months therapy, Consolidation on CT disappeared, and Nocardiosis was cured.
\end{abstract}

Conclusion: we reported the first case of pulmonary nocardiosis caused by N. exalbida in an immunocompetent patient. N. exalbida infection might be associated with a good response to treatment.

Keywords: Nocardia exalbida, Infection, Pulmonary nocardiosis, Immunocompetent patient

\footnotetext{
* Correspondence: ytanabe2713@gmail.com

'Department of Respiratory Medicine, Niigata prefecturasl Shibata hospital,

1-2-8 Shibata, Niigata 957-8588, Japan

Full list of author information is available at the end of the article
}

\section{$\triangle B M C$}

C C The Author(s). 2021 Open Access This article is licensed under a Creative Commons Attribution 4.0 International License, which permits use, sharing, adaptation, distribution and reproduction in any medium or format, as long as you give appropriate credit to the original author(s) and the source, provide a link to the Creative Commons licence, and indicate if changes were made. The images or other third party material in this article are included in the article's Creative Commons licence, unless indicated otherwise in a credit line to the material. If material is not included in the article's Creative Commons licence and your intended use is not permitted by statutory regulation or exceeds the permitted use, you will need to obtain permission directly from the copyright holder. To view a copy of this licence, visit http://creativecommons.org/licenses/by/4.0/ The Creative Commons Public Domain Dedication waiver (http://creativecommons.org/publicdomain/zero/1.0/) applies to the data made available in this article, unless otherwise stated in a credit line to the data. 


\section{Back ground}

The genus Nocardia is an aerobic bacterium, Grampositive and catalase positive that is in the Nocardiaceae family [1]. Since Edmond Nocard isolated an aerobic filamentous organism from lesions in cattle suffering from fancy in 1888 and Trevisan created the genus Nocardia to accommodate Nocard's isolate and named it Nocardia farcinica [1], Nocardia species are classified by various methods that have morphological, biochemical, physiological and chemotaxonomic properties.

Of particular interest, the recent introduction of molecular methods, such as sequencing of the 16S rRNA gene, allows for more accurate clarification of the taxonomy of Nocardia and new findings are updated. The identification of the Nocardia species in nocardiosis is important because the drug susceptibility differs among the species [2].

Nocardiosis is known as an opportunistic infection in immunocompromised hosts, but occasionally it has been reported in immunocompetent patient [3]. The data about worldwide incidence of Nocardia infection is limited and unclear. In An American study, Annual incidence of nocardiosis in United State is about 500-1000 cases per year [4]. However some literature points out this incidence was greatly underestimated [5]. Meanwhile, the incidence of nocardiosis may be increasing because of the growing number of immunocompromised patients treated with advances in medical treatment. Nocardia infects the lungs, skin, central nervous system (CNS) or other organs presenting as localized or disseminated infections. Pulmonary nocardiosis is the main type of nocardiosis. Nocardiosis involves the lung in $60-$ $70 \%$ of cases [6].

We herein report a case of pulmonary nocardiosis caused by $N$. exalbida in a patient who is nonimmunocompromised and review the reported cases of N. exalbida infection.

\section{Case presentation}

A 77-year-old Japanese man was admitted to our hospital on November 2, 2018. One month before this admission, fevers, sputum, mild cough were developed, and the patient was evaluated in a community clinic. He was a lifelong non-smoker with no childhood history of respiratory disease. A chest $\mathrm{x}$-ray showed consolidation on his right lung field. A clinical diagnosis of right pneumonitis was made. The $\alpha$-streptococcus was isolated from his sputum. He was treated with ceftriaxone intravenously for a week, his symptoms relapsed a few days later. He was re -treated with ceftriaxone for 3 days, his symptoms did not show improvement. The patient was referred to our hospital for management of refractory pneumonitis. His body height was $5^{\prime} 2^{\prime \prime}(162 \mathrm{~cm})$, his body weight was $63 \mathrm{~kg}$, and his body mass index was 23.6 .
On physical examination, his consciousness level was clear (GCS; E4V5M6), pulse was 92 beats per minute, respiratory rate was 18 breaths per minute, blood pressure was $119 / 72 \mathrm{mmHg}$, temperature was $36.7^{\circ} \mathrm{C}\left(98.1^{\circ} \mathrm{F}\right)$, and oxygen saturation was $96 \%$ (room air). Auscultation of his lungs revealed that there was decreasing lung sound in his right middle lung field, dermatological findings and neurologic findings were normal. Laboratory evaluation showed an elevated peripheral blood white blood cell count of $13,000 / \mu \mathrm{L}$ with $88.4 \%$ neutrophils, and a C-reactive protein level of $11.29 \mathrm{mg} / \mathrm{dL}$. Baseline investigations for immunodeficiency had normal results. No pathogenic bacteria were detected from a sputum culture. Sputum cytology was class II and neutrophil were abundant. We prescribe sitafloxacin for one more week, however his temperature increased to $38.3^{\circ} \mathrm{C}$ $\left(100.9^{\circ} \mathrm{F}\right)$ with right chest pain, bloody sputum, and general malaise. A chest $\mathrm{x}$-ray showed consolidation on his right lung field (Fig. 1). A chest computed tomography (CT) scan showed consolidation and atelectasis in his right middle lobe. Low density area was scattered in consolidation, and right pleural effusion was observed (Fig. 2). He was diagnosed with pulmonary abscess and he was admitted. The laboratory findings on admission (Table 1) demonstrated an elevated peripheral blood white blood cell count $(16,100 / \mu \mathrm{L})$ and a CRP level (17.9 mg/dL).

Administration of piperacillin/tazobactam $4.5 \mathrm{~g}$ q6hr improved the symptoms. On day 12 from admission, his right pleural effusion disappeared on chest x-ray (Fig. 3), and CRP decreased to $0.17 \mathrm{mg} / \mathrm{dL}$. We switched

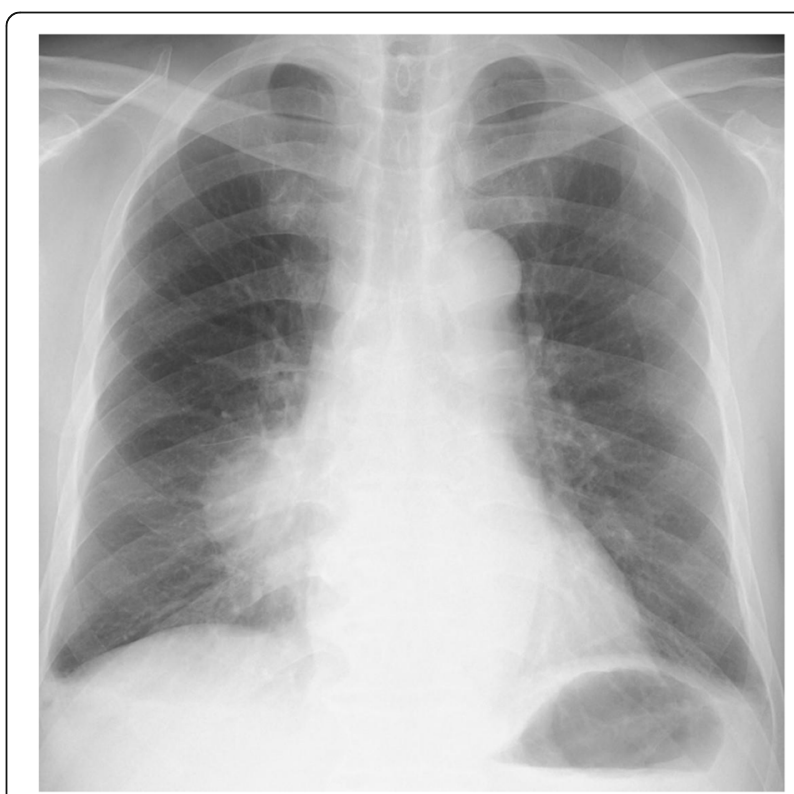

Fig. 1 Chest X-ray on 1st admission at the hospital. Consolidation was present in the right lower lung field, and the costophrenic angle was blunted on the right side 


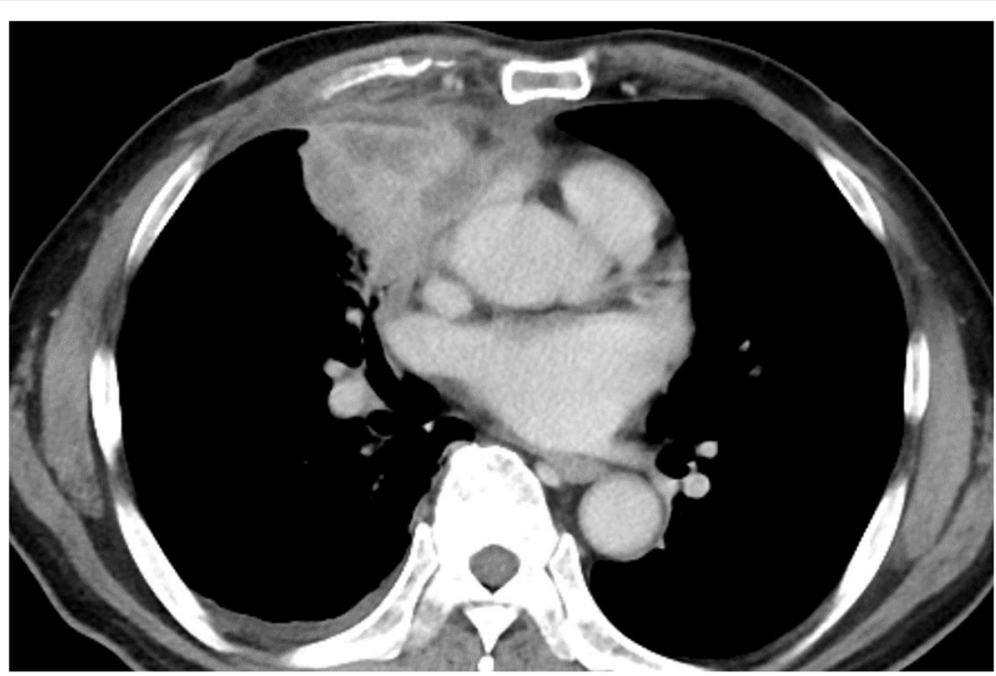

Fig. 2 Contrast-enhanced thoracic computed tomography on 1st admission at the hospital. Lung abscess formation was present in right middle lobe. Low density area was scattered in consolidation, and right pleural effusion was present

Table 1 Laboratory Findings on Admission

\begin{tabular}{|c|c|c|}
\hline \multicolumn{3}{|l|}{ <Blood cell count> } \\
\hline White blood cell & 16,100 & $/ \mu \mathrm{L}$ \\
\hline Red blood cell & 405 & $\times 10^{4} / \mu \mathrm{L}$ \\
\hline Hemoglobin & 11.9 & $\mathrm{~g} / \mathrm{dL}$ \\
\hline Hematocrit & 35.5 & $\%$ \\
\hline Platelet & 27.4 & $\times 10^{4} / \mu \mathrm{L}$ \\
\hline \multicolumn{3}{|l|}{$<$ Serum chemistry $>$} \\
\hline Total Protein & 6.6 & $\mathrm{~g} / \mathrm{dL}$ \\
\hline Blood urea nitrogen & 18 & $\mathrm{mg} / \mathrm{dL}$ \\
\hline Creatinine & 0.79 & $\mathrm{mg} / \mathrm{dL}$ \\
\hline Total-bilirubin & 1.2 & $\mathrm{mg} / \mathrm{dL}$ \\
\hline Aspartate transaminase & 60 & $U / L$ \\
\hline Alanine transaminase & 76 & $U / L$ \\
\hline Alkaline phosphatase & 304 & $U / L$ \\
\hline ү -Glutamyl transpeptidase & 50 & $U / L$ \\
\hline Lactate dehydrogenase & 185 & $U / L$ \\
\hline $\mathrm{Na}$ & 137 & $\mathrm{mEq} / \mathrm{L}$ \\
\hline $\mathrm{K}$ & 4.4 & $\mathrm{mEq} / \mathrm{L}$ \\
\hline $\mathrm{Cl}$ & 102 & $\mathrm{mEq} / \mathrm{L}$ \\
\hline C-reactive protein & 17.9 & $\mathrm{mg} / \mathrm{dL}$ \\
\hline $\mathrm{HbA1C}$ & 5.0 & $\%$ \\
\hline \multicolumn{3}{|l|}{$<$ Infection> } \\
\hline$\beta$-D glucan & $<6$ & $\mathrm{pg} / \mathrm{ml}$ \\
\hline Aspergillus Antigen & Negative & \\
\hline C.neoformans Antigen & Negative & \\
\hline Anti-HIV Ab & Negative & \\
\hline \multicolumn{3}{|l|}{ <Tumor marker> } \\
\hline CEA & 1.8 & $\mathrm{ng} / \mathrm{mL}$ \\
\hline SCC & 1.2 & $\mathrm{ng} / \mathrm{mL}$ \\
\hline CYFRA & 1.7 & $\mathrm{ng} / \mathrm{mL}$ \\
\hline NSE & 8.1 & $\mathrm{ng} / \mathrm{mL}$ \\
\hline
\end{tabular}

antibiotic piperacillin/tazobactam to amoxicillin/clavulanate, and he was discharged on Day 14 without fever. After 2 weeks, the patient became febrile, and CRP was elevated to $6.35 \mathrm{mg} / \mathrm{dL}$ again. His lung abscess relapsed despite of intaking amoxicillin/clavulanate after he was discharged (Fig. 4). He was admitted again.

We decided to commence re-administration of piperacillin/tazobactam $4.5 \mathrm{~g}$ q6hr for 3 weeks. Despite getting his symptoms and clinical findings to recover in just 1 week, chest CT findings on day 21 at second admission showed little improvement. We decided to perform

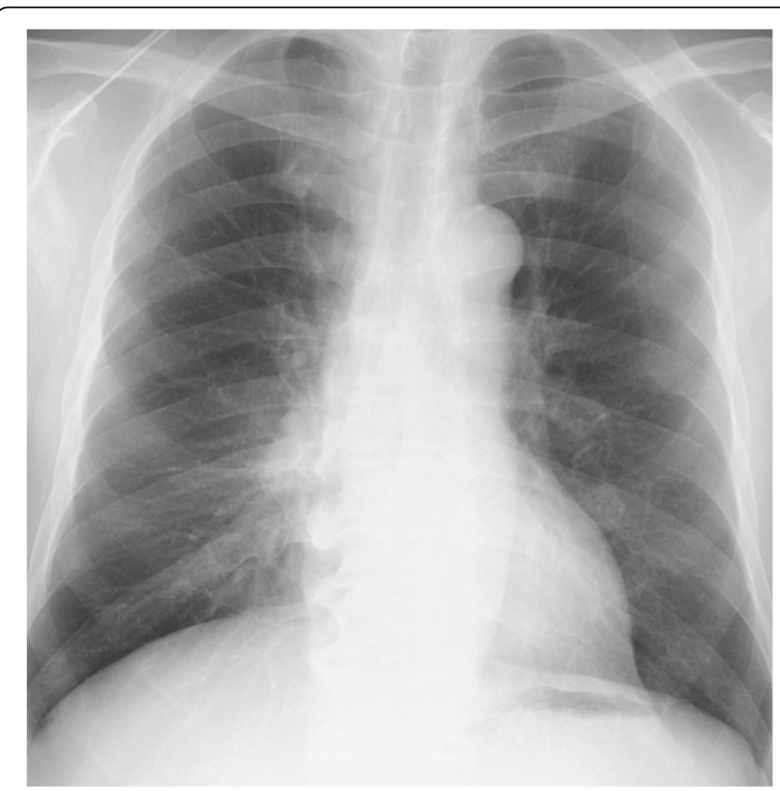

Fig. 3 Chest X-ray on 1st discharge at the hospital. Consolidation in the right lower lung field and right pleural effusion were almost disappeared 


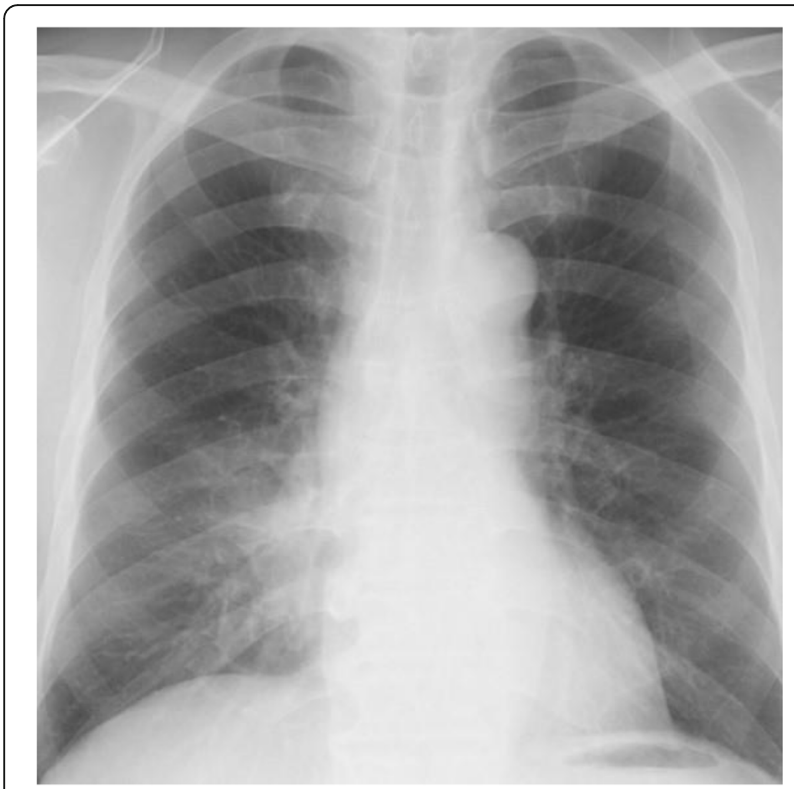

Fig. 4 Chest $X$-ray on 2nd admission at the hospital. Consolidation in the right lower lung field was relapsed

bronchoscopy. Bronchial washing and transbronchial lung biopsy through right $\mathrm{B}^{5 \mathrm{~b}}$ were performed. Grampositive, filamentous, branching rods were found by Gram stain (Fig. 5), and negative examination of Ziehl-Neelsen stain. Nocardia species were cultured from samples of the bronchial wash.

After we confirm by brain CT scan that no brain abscess existed, we switched to TMP/SMX. He was an immunocompetent patient, and he did not have a CNS problem. Susceptibility testing was performed according to Clinical and Laboratory Standards Institute (CLSI) document M24-A; the specific susceptible breakpoint of
TMP/SMX for Nocardia species was $\leq 2 / 38$ and the specific resistance breakpoint was $\geq 4 / 76$. The MICs of TMP/SMX for $N$. exalbida were $0.25 / 4.75$. Thus, the $N$. exalbida was regarded as sensitive to TMP/SMX (Table 2). We decided to prescribe TMP/SMX 2 tablets BID (approximately $5 \mathrm{mg}$ (per $\mathrm{kg}$ of body weight) for the TMP component). Treatment response was good, but renal dysfunction occurred from administration of TMP/SMX 4 months later. We switched to minocycline $100 \mathrm{mg}$ po BID for 1 month. After treatment, we confirmed that consolidation on CT had disappeared, and he has not relapsed. With the corporation of the Medical Mycology Research Center of Chiba University, the isolates were identified as $N$. exalbida using $16 \mathrm{~S}$ rRNA gene sequencing.

\section{Discussion and conclusion}

Pulmonary nocardiosis mainly occurs as an opportunistic infection in immunocompromised patients, particularly in those with defect in cell-mediated immunity such as patients with human immunodeficiency virus (HIV) infection and those receiving long-term systemic steroids or immunosuppressive agents. Pulmonary nocardiosis often occurs with chronic obstructive pulmonary disease (COPD) and bronchiectasis [7]. We cannot point out any underlying disease that cause an immunocompromised state (ex. human immunodeficiency virus infection, diabetes) and no malignant disease has developed in the follow up period.

There is no report that discussed the infection route in the past $N$. exalbida case reports. But other pulmonary nocardiosis was often described from environmental history. In our case he was doing gardening as a hobby and might have inhaled from soil.

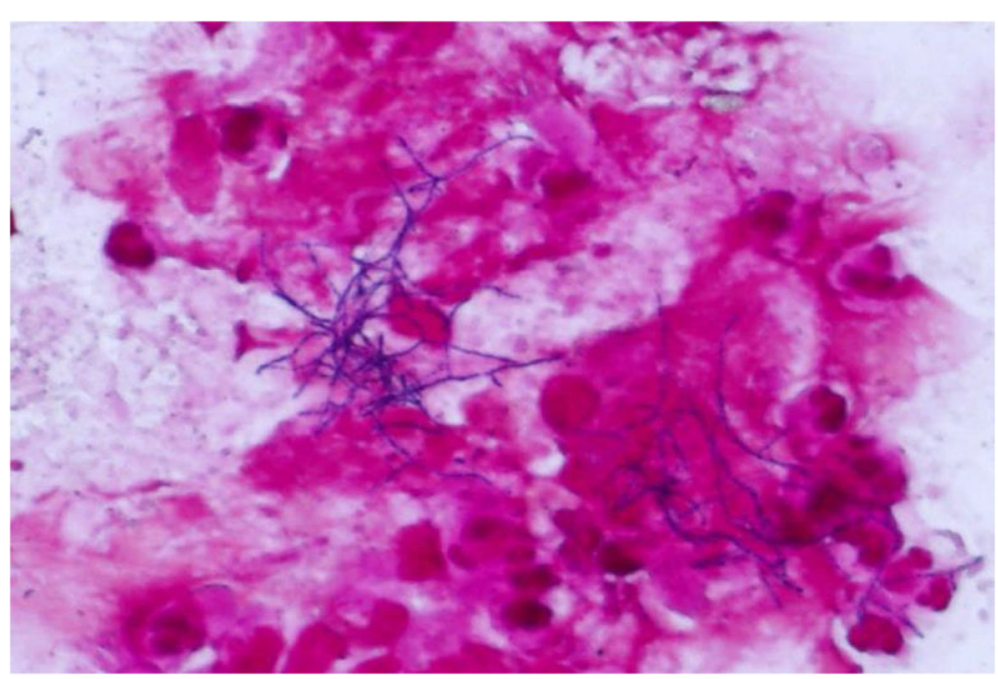

Fig. 5 Gram stain $(\times 1000)$ of bronchial lavage fluid showing gram-positive, branching, beaded filaments 
Table 2 Antimicrobial susceptibilities of Nocardia exalbida isolated from Brochial wash fulid cultures

\begin{tabular}{ll}
\hline Minimum inhibitory concentration $(\boldsymbol{\mu g} / \mathbf{m L})$ & $>8$ \\
\hline Ampicillin & 4 \\
Ceftriaxone & 1 \\
Imipenem & 2 \\
Minocycline & $0.2 / 4.75$ \\
Trimethoprim/Sulfamethoxazole & $<4$ \\
Amikacin & $<0.5$ \\
Gentamicin & 4 \\
Ciprofloxacin & 4 \\
Clarithromycin & $>2$ \\
Erythromycin &
\end{tabular}

Susceptibility differs among the species [2]. TMP-SMX is active against most Nocardia species; however, $N$. otitidiscaviarum is commonly resistant to TMP-SMX, and N.nova and N. farcinica are occasionally resistant [8]. So, it is important to identify of Nocardia species and determine antimicrobial susceptibility.

$N$. exalbida was first isolated from two immunocompromised patients with a cutaneous lesion and lung abscess in 2006 [9]. To date,10 cases of nocardiosis caused by $N$. exalbida have been reported (Table 3).

Only 6 cases of pulmonary nocardiosis were reported including our case $[10,12,14]$, one each with brain abscess [11], keratitis [10], endophthalmitis [13], blebitis [15], and pemphigus vulgaris [9].

All the former cases of pulmonary nocardiosis occurred in immunocompromised patients. Our case is the first reported case of pulmonary nocardiosis by $N$. exalbida in immunocompetent patient.

In the outcomes of all these cases, death by nocardiosis or poor response to treatment for $N$. exalbida infection had not been reported (including two cases where the outcome is unknown and one case is died due to progressive lung cancer).

$N$. exalbida infection might be associated with a good response to treatment [16]. In one case that had pneumonia with $N$. exalbida with HIV the patient was treated with TMP/SMX six tablet (approximately $12 \mathrm{mg}$ per $\mathrm{kg}$ of body weight) for the TMP component) monotherapy for 12 month and cure [14]. In our case we prescribed TMP/SMX 4 tablets (approximately $5 \mathrm{mg}$ per $\mathrm{kg}$ of body weight) for the TMP component) monotherapy for 4 months and switched to minocycline for 1 month because renal injury induced by TMP/SMX had been

Table 3 Literature review of Nocardia exalbida infection

\begin{tabular}{|c|c|c|c|c|c|c|}
\hline Reference & $\begin{array}{l}\text { Age } \\
\text { /sex }\end{array}$ & Disease & Underlying condition & Treatment & Duration for Antibiotics & Outcome \\
\hline [9] & $43 / N R$ & Pneumonia & NR & NR & NR & NR \\
\hline [9] & $60 / \mathrm{NR}$ & NR & Pemphigus -vulgaris & NR & NR & NR \\
\hline [10] & $38 / F$ & Keratitis & None & $\begin{array}{l}\text { Erytromycin + topical agent } \\
\rightarrow \text { TMP/SMX(3 tablets/day) } \\
\text { +topical agent }\end{array}$ & $\begin{array}{l}\text { unclear } \\
10 \text { days } \\
\text { unclear }\end{array}$ & Improved \\
\hline [11] & $63 / M$ & Brain abscess & Lymphoma & $\begin{array}{l}\operatorname{TMP} / \mathrm{SMX}(13 \mathrm{mg} / \mathrm{kg} / \text { day }) \\
+\operatorname{MEPM}(4 \mathrm{~g} / \text { day }) \\
\rightarrow \operatorname{TMP} / \mathrm{SMX}(11.5 \mathrm{mg} / \mathrm{kg} / \text { day })^{\mathrm{a}}\end{array}$ & $\begin{array}{l}2 \text { months } \\
2 \text { months } \\
>4 \text { months }\end{array}$ & Improved \\
\hline [12] & $47 / M$ & Pneumonia & $\mathrm{HIV}, \mathrm{DM}, \mathrm{HB}$ & $\begin{array}{l}\text { IMP(2 g/day) } \\
\text { AMK(15 mg/kg/day) } \\
\rightarrow \text { GRNX(400 mg/day })^{a}\end{array}$ & $\begin{array}{l}17 \text { days } \\
17 \text { days } \\
6 \text { months }\end{array}$ & Improved \\
\hline [13] & $56 / M$ & Endophthalmitis & None & $\begin{array}{l}\text { TMP/SMX (unknown } \\
\rightarrow \text { Enucleation }\end{array}$ & 6 months & Improved \\
\hline [14] & $68 / M$ & Pneumonia & HIV & $\begin{array}{l}\text { TMP/SMX(12 mg/kg/day) } \\
\rightarrow \operatorname{TMP} / S M X(6 \text { mg/kg/day) }\end{array}$ & $\begin{array}{l}7 \text { days } \\
12 \text { months }\end{array}$ & Improved \\
\hline \multirow[t]{3}{*}{ [15] } & $57 / M$ & Blebitis & Open-angle glaucoma & TMP/SMX (unknown) & & Improved \\
\hline & & & & +AMK (unknown) & 6 months & \\
\hline & & & & +Sulfonamide (unknown) & & \\
\hline [16] & $70 / \mathrm{M}$ & Pneumonia & $\begin{array}{l}\text { Lung cancer } \\
\text { oral steroids }\end{array}$ & $\begin{array}{l}\operatorname{DRPM}(3.0 \mathrm{~g} / \mathrm{day}) \\
+\mathrm{TMP} / \mathrm{SM} X(13 \mathrm{mg} / \mathrm{kg} / \text { day })\end{array}$ & $\begin{array}{l}17 \text { days } \\
8 \text { days }\end{array}$ & $\underset{b}{\text { Improved }}$ \\
\hline [17] & $76 / M$ & Pneumonia & Colon cancer & $\begin{array}{l}\text { TMP/SMX (unknown) } \\
\rightarrow \text { TMP-SMX + LVFX }\end{array}$ & 3 months & Improved \\
\hline Present case & $77 / M$ & Pneumonia & None & $\begin{array}{l}\text { TMP/SMX (5 mg/kg/day) } \\
\rightarrow \text { Minocycline } 200 \text { mg }\end{array}$ & $\begin{array}{l}4 \text { months } \\
1 \text { month }\end{array}$ & Improved \\
\hline
\end{tabular}


suspected. In our case, the response to treatment was good. It was considered that a dose reduction of TMP/ SMX in case of $N$. exalbida infection without CNS lesion might occur in an immunocompetent patient.

In general, long-term treatment is recommended for patients with CNS lesions (ex. Brain abscess) or severe immunodeficiency, but there is no consensus on N. exalbida even in immunocompetent patient. We considered the disappearance of the abscess as a goal of treatment.

In this case, a diagnosis was delayed. We could not assume pulmonary nocardiosis because our patient did not have an underlying disease except for dyslipidemia and clinically improved immediately following treatment with piperacillin/tazobactam on 1st admission. We could determine causative microorganism and antimicrobial susceptibility performing bronchoscopy on 2nd admission.

Although the symptoms improved with the initial treatment, the abscess remained even after the inflammation improved, so it is probable that he was infected with Nocardia at the time of initial hospitalization.

In conclusion, we reported a case of pulmonary nocardiosis caused by $N$. exalbida in an immunocompetent patient. N. exalbida infection might be associated with a good response to treatment. We expect a further accumulation of the clinical characteristics of $N$. exalbida.

\section{Abbreviations}

CT: computed tomography; $16 \mathrm{~S}$ rRNA: $16 \mathrm{~S}$ ribosomal RNA; TMP/

SMX: Trimethoprim/sulfamethoxazole; CRP: C-reactive protein; GCS: Glasgow Coma Scale

\section{Acknowledgments}

We thank Takashi Yaguchi, Medical Mycology Research Center, Chiba University, for identifying the Nocardia species.

\section{Authors' contributions}

SA writes first version of the manuscript, and $\mathrm{YT}$ completed all documents. $\mathrm{SA}, \mathrm{TO}, \mathrm{FF}, \mathrm{AY}$ and $\mathrm{MM}$ were responsible for the treatment of the patients. YT supervised the treatment and the completion of this case report. All authors read and approved the final manuscript.

\section{Funding}

None.

\section{Availability of data and materials}

All data discussed in the manuscript are included within this published article.

\section{Declarations}

Ethics approval and consent to participate

Not applicable.

\section{Consent for publication}

Written informed consent for publication of the case report was obtained from the patient.

\section{Competing interests}

The authors declare that they have no competing interests.

\section{Author details}

'Department of Respiratory Medicine, Niigata prefecturasl Shibata hospital, 1-2-8 Shibata, Niigata 957-8588, Japan. 'Department of Infectious Disease, Niigata City general hospital, Niigata, Japan.

Received: 10 January 2021 Accepted: 5 July 2021

Published online: 09 August 2021

\section{References}

1. Fatahi-Bafghi M. Nocardiosis from 1888 to 2017. Microb Pathog. 2018;114: 369-84.

2. Lerner PI. Nocardiosis. Clin Infect Dis. 1996;22(6):891-903 quiz 904-895.

3. Alavi Darazam I, Shamaei M, Mobarhan M, Ghasemi S, Tabarsi P, Motavasseli $\mathrm{M}$, et al. Nocardiosis: risk factors, clinical characteristics and outcome. Iran Red Crescent Med J. 2013;15(5):436-9.

4. Beaman BL, Burnside J, Edwards B, Causey W. Nocardial infections in the United States, 1972-1974. J Infect Dis. 1976;134(3):286-9.

5. Beaman BL, Beaman L. Nocardia species: host-parasite relationships. Clin Microbiol Rev. 1994;7(2):213-64.

6. Lederman ER, Crum NF. A case series and focused review of nocardiosis: clinical and microbiologic aspects. Medicine (Baltimore). 2004;83(5):300-13.

7. Wilson JW. Nocardiosis: updates and clinical overview. Mayo Clin Proc. 2012; 87(4):403-7.

8. Mcneil MM. Evaluation of therapy for nocardia-asteroides complex infections. Infect Dis Clin Prac. 1995;4(4):287-92.

9. lida S, Kageyama A, Yazawa K, Uchiyama N, Toyohara T, Chohnabayashi N, et al. Nocardia exalbida sp. nov., isolated from Japanese patients with nocardiosis. Int J Syst Evol Microbiol. 2006;56(Pt 6):1193-6.

10. Mizota A, Haki K, Shiina C, Tanaka M, Nakazawa T, Yazawa K, et al. The first case of keratitis caused by Nocardia exalbida. Int Ophthalmol. 2007;27(5): 333-6.

11. Ono M, Kobayashi Y, Shibata T, Maruyama D, Kim SW, Watanabe T, et al. Nocardia exalbida brain abscess in a patient with follicular lymphoma. Int J Hematol. 2008;88(1):95-100.

12. Imai K, Koibuchi T, Kikuchi T, Koga M, Nakamura H, Miura T, et al. Pulmonary nocardiosis caused by Nocardia exalbida complicating Pneumocystis pneumonia in an HIV-infected patient. J Infect Chemother. 2011:17(4):547-51.

13. Milman T, Trubnik V, Shah M, McCormick SA, Finger PT. Isolated Nocardia exalbida endogenous endophthalmitis. Ocul Immunol Inflamm. 2011;19(4): 237-9.

14. Kiyasu Y, Koganemaru H, Kurihara Y, Hitomi S. Pulmonary infection due to Nocardia exalbida complicated with pneumococcal pneumonia. JMM Case Rep. 2015;2(4):e000082.

15. Ifantides $C$, Batlle OR, Mushatt D, Ayyala RS. Nocardia exalbida blebitis: a case report. J Glaucoma. 2015;24(4):e19-21.

16. Kato K, Noguchi S, Naito K, Ikushima I, Hanaka T, Yamasaki K, et al. Pulmonary nocardiosis caused by nocardia exalbida in a patient with lung cancer and radiation pneumonitis: a case report and literature review. Intern Med. 2019;58(11):1605-11.

17. Miyaoka C, Nakamoto K, Shirai T, Miyamoto M, Sasaki Y, Ohta K. Pulmonary nocardiosis caused by Nocardia exalbida mimicking lung cancer. Respirol Case Rep. 2019;7(7):e00458.

\section{Publisher's Note}

Springer Nature remains neutral with regard to jurisdictional claims in published maps and institutional affiliations.

Ready to submit your research? Choose BMC and benefit from:
- fast, convenient online submission
- thorough peer review by experienced researchers in your field
- rapid publication on acceptance
- support for research data, including large and complex data types
- gold Open Access which fosters wider collaboration and increased citations
- maximum visibility for your research: over 100M website views per year
At BMC, research is always in progress.
Learn more biomedcentral.com/submissions

